Article

\title{
Evaluating Three-Pillar Sustainability Modelling Approaches for Dairy Cattle Production Systems
}

\author{
Xabier Díaz de Otálora ${ }^{1,2, *(\mathbb{D}}$, Agustín del Prado ${ }^{2}$, Federico Dragoni ${ }^{1}\left(\mathbb{D}\right.$, Fernando Estellés ${ }^{3}(\mathbb{D}$ \\ and Barbara Amon 1,4 \\ 1 Leibniz-Institute for Agricultural Engineering and Bioeconomy (ATB), 14469 Potsdam, Germany; \\ FDragoni@atb-potsdam.de (F.D.); bamon@atb-potsdam.de (B.A.) \\ 2 Basque Centre for Climate Change (BC3), 48940 Leioa, Spain; agustin.delprado@bc3research.org \\ 3 Institute of Animal Science and Technology, Universitat Politècnica de València, 46022 Valencia, Spain; \\ feresbar@upv.es \\ 4 Faculty of Civil Engineering, Architecture and Environmental Engineering, University of Zielona Góra, \\ 65-417 Zielona Góra, Poland \\ * Correspondence: xdiaz@atb-potsdam.de; Tel.: +49-33156990
}

check for updates

Citation: Díaz de Otálora, X.; del Prado, A.; Dragoni, F.; Estellés, F.; Amon, B. Evaluating Three-Pillar Sustainability Modelling Approaches for Dairy Cattle Production Systems. Sustainability 2021, 13, 6332.

https://doi.org/10.3390/su13116332

Academic Editor: Giuseppe Todde

Received: 26 April 2021

Accepted: 1 June 2021

Published: 3 June 2021

Publisher's Note: MDPI stays neutral with regard to jurisdictional claims in published maps and institutional affiliations.

Copyright: (c) 2021 by the authors. Licensee MDPI, Basel, Switzerland. This article is an open access article distributed under the terms and conditions of the Creative Commons Attribution (CC BY) license (https:// creativecommons.org/licenses/by/ $4.0 /)$.

\begin{abstract}
Milk production in Europe is facing major challenges to ensure its economic, environmental, and social sustainability. It is essential that holistic concepts are developed to ensure the future sustainability of the sector and to assist farmers and stakeholders in making knowledge-based decisions. In this study, integrated sustainability assessment by means of whole-farm modelling is presented as a valuable approach for identifying factors and mechanisms that could be used to improve the three pillars (3Ps) of sustainability in the context of an increasing awareness of economic profitability, social well-being, and environmental impacts of dairy production systems (DPS). This work aims (i) to create an evaluation framework that enables quantitative analysis of the level of integration of 3P sustainability indicators in whole-farm models and (ii) to test this method. Therefore, an evaluation framework consisting of 35 indicators distributed across the 3Ps of sustainability was used to evaluate three whole-farm models. Overall, the models integrated at least $40 \%$ of the proposed indicators. Different results were obtained for each sustainability pillar by each evaluated model. Higher scores were obtained for the environmental pillar, followed by the economic and the social pillars. In conclusion, this evaluation framework was found to be an effective tool that allows potential users to choose among whole-farm models depending on their needs. Pathways for further model development that may be used to integrate the 3P sustainability assessment of DPS in a more complete and detailed way were identified.
\end{abstract}

Keywords: sustainability; dairy farm; integrated; whole-farm models; evaluation

\section{Introduction}

The global demand for livestock products is expected to increase by up to $70 \%$ by 2050 [1]. In this context, dairy production systems (DPS) constitute an essential backbone of European agriculture, producing high-quality protein products that are key for our diets by means of fibrous feed resources that cannot be directly utilized by humans or converted to human food by monogastric animals [2,3]. Products derived from this sector (mainly milk and its derivatives) represent the largest animal product category in the European Union (EU) [4]. The high level of production linked to the increasing demand for these products by EU citizens [5] highlights the importance of this sector from economic, social, and environmental points of view. In addition, the livestock sector, and in particular the DPS, is a potential contributor within the framework of the circular economy [6,7]. Livestock are resource recyclers by nature, but the conditions under which livestock can enhance circularity and play a decisive role in the development of more sustainable farming systems need to be defined. The circular bioeconomy requires a switch from maximizing 
single products and single process efficiency to having a comprehensive focus on the use of resources within the whole food system and the integration of production systems in territories and food chains [8,9].

In previous decades, multiple initiatives aimed at expanding existing knowledge on livestock system sustainability assessments have arisen on different geographical scales. The Global Research Alliance (GRA) aims to reduce the emission intensity of livestock production systems by optimizing food production $[10,11]$. In addition, through the guidelines for Sustainability Assessment of Food and Agricultural Systems (SAFA), the Food and Agriculture Organization of the United Nations (FAO) has developed a framework that could serve as a holistic tool for the assessment of sustainability in food and agriculture value chains $[12,13]$. At the European scale, the Modelling European Agriculture with Climate Change and Food Security initiative (MACSUR) highlights the existence of different sustainability assessment models in the context of livestock and agriculture, enhancing the integration between them $[14,15]$. Created under the framework of the EU Joint Programming Initiative for Agriculture, Climate Change, and Food Security, MACSUR also aims to analyze the contributions of these models in terms of coping with climate change in the EU by, for example, using integrated modelling in the animal production sector.

There is an urgent demand for identification and quantitative assessment of win-win (synergy) or second-best (trade-off) solutions by improving knowledge of the systemic relationships in such complex systems [16]. The ability to account for interactions among livestock systems, the environment, and on-farm management decisions makes integrated modelling an appropriate approach when assessing sustainability in DPS [17]. Application of this integrated approach has been described as indispensable for understanding the different interacting subsystems inside a farm [18]. When integrating aspects using the 3Ps of sustainability, it is necessary to identify, describe, and analyze the different external factors, both positive and negative, associated with livestock activity [19]. For instance, the generation of employment throughout the production chain and the production of high-quality protein products for consumption in less developed areas are considered positive effects of livestock that are related to all three pillars of sustainability [20]. In contrast, the negative external factors associated with sustainability derived from livestock activities are mainly due to their contributions to greenhouse gas (GHG) and nitrogen $(\mathrm{N})$ emissions and the use of natural resources [21,22]. In the process of identification, analysis, and evaluation of these sustainability aspects, farm-level assessment tools are highly valuable for researchers, practitioners, and farmers [23,24]. In this context, wholefarm models are presented as appropriate tools to encompass individual farm processes through a complete and integrated dairy system assessment [25]. These tools allow the quantification of socioeconomic and biophysical farm processes in order to achieve concrete management objectives according to specific farm situations [26].

Whole-farm integrated sustainability modelling requires clear identification of both the inputs of the system and the outputs derived from the livestock activity itself. An ideal whole-farm model should be able to integrate attributes of the three pillars of sustainability as well as represent existing synergies and trade-offs between them [27]. It is essential that holistic concepts are developed to ensure the sustainable economic, environmental, and social development of DPS. By integrating economic, social, and environmental sustainability indicators into the assessment, synergies, and trade-offs of economic costs, social and environmental impacts can be quantified, leading the sector on a more socioeconomically and environmentally sustainable path. To date, a wide variety of whole-farm sustainability assessment tools with different objectives have been developed [28]. However, limited attention has been paid to the evaluation processes associated with these tools, resulting in a lack of guidance when deciding which tool should be used [29].

The sustainability of agricultural production has moved to the forefront of public concern and the political agenda [30,31]. The use of an integrated approach when evaluating the sustainability of DPS has been described as a very effective method to satisfy the economic needs of farmers, the well-being of society, and the environmental conditions in 
which livestock activity takes place [32,33]. In this context, the use of a common framework for evaluating the suitability of models to assess 3P sustainability in DPS allows clear boundaries on what a balanced model should analyze to be established, enabling informed selection of which model to use.

For these reasons, the aim of this paper is to establish and test a framework that can be used to evaluate the suitability of models to assess 3P sustainability in DPS. This method allows the different aspects of tools related to the 3Ps of sustainability to be investigated and the level of completeness with which the proposed indicators are integrated to be assessed, facilitating the selection of the tool that best fits the needs of the users.

\section{Materials and Methods}

\subsection{Evaluation Framework}

An in-depth analysis was carried out with the objective of identifying the number and typologies of the sustainability indicators used in the existing literature. For this purpose, a literature search was carried out using the Scopus database. Papers including the terms "sustainability indicators" and "livestock farming" in the title, abstract, or keywords were considered. The search was carried out in December 2020.

As a primary output, 21 references were identified, from 3 papers (Table 1) for which the following criteria applied: (i) only articles published in English-language peer-reviewed journals were selected; (ii) the papers should include indicators of the three pillars of sustainability (economic, social, and environmental); and (iii) the context of application of the indicators included in these papers is focused on the dairy industry (both dairy cattle and sheep). Papers whose scope was not directly related to the sustainability of DPS as a whole (e.g., sustainability of cropping systems only) were excluded from this analysis.

Table 1. Final literature review output for the indicator compilation.

\begin{tabular}{cccc}
\hline Reference & Journal & Publication Year & DOI \\
\hline$[34]$ & $\begin{array}{c}\text { Sustainability } \\
\text { Agronomy for }\end{array}$ & 2017 & $10.3390 /$ su9091615 \\
{$[35]$} & $\begin{array}{c}\text { Sustainable } \\
\text { Development }\end{array}$ & 2013 & $10.1007 / \mathrm{s} 13593-012-0121-x$ \\
{$[36]$} & Agricultural Systems & 2011 & $10.1016 /$ j.agsy.2011.10.003 \\
\hline
\end{tabular}

A list of 35 indicators was derived from the three selected papers (Table 2): 11 within the economic pillar, 7 within the social pillar, and 17 within the environmental pillar. The economic pillar indicators included aspects associated with profitability, autonomy, farm diversification, and durability. Social sustainability was represented by indicators related to education, working conditions, quality of life, and ecosystem services. Environmental sustainability incorporated indicators related to farm management, greenhouse gases and reactive nitrogen emissions, and soil/water quality.

Table 2. List of the indicators for the 3Ps of sustainability used for the evaluation framework.

\begin{tabular}{ccc}
\hline Sustainability Pillar & Attribute & Indicator \\
\hline Economic $(n=11)$ & Profitability & Net farm income \\
& & Land productivity \\
& Animal productivity \\
& Feed efficiency \\
& Autonomy & Economic self-sufficiency \\
& Farm diversification & Foed self-sufficiency \\
& & Economic diversification \\
& Nonfood earnings \\
& Durability & Added value products \\
& Succession and transmissibility \\
\hline
\end{tabular}


Table 2. Cont.

\begin{tabular}{|c|c|c|}
\hline Sustainability Pillar & Attribute & Indicator \\
\hline \multirow[t]{7}{*}{ Social $(n=7)$} & Working conditions & Work balance \\
\hline & & Labor efficiency \\
\hline & Quality of life & $\begin{array}{c}\text { Job satisfaction and personal } \\
\text { development }\end{array}$ \\
\hline & & Animal welfare \\
\hline & Ecosystem services & Environmental conservation \\
\hline & & Landscape maintenance \\
\hline & & Ecosystem regulation \\
\hline \multirow[t]{17}{*}{ Environmental $(n=17)$} & Farm management & Land use \\
\hline & & Erosion \\
\hline & & Energy use \\
\hline & & Water use \\
\hline & & Pesticide use \\
\hline & Reactive nitrogen $\left(\mathrm{N}_{\mathrm{r}}\right)$ & $\mathrm{NH}_{3}$ emissions \\
\hline & & $\mathrm{NO}_{\mathrm{X}}$ emissions \\
\hline & Greenhouse gases & $\mathrm{CH}_{4}$ enteric fermentation \\
\hline & & $\mathrm{CH}_{4}$ manure \\
\hline & & $\mathrm{N}_{2} \mathrm{O}$ soils \\
\hline & & $\mathrm{N}_{2} \mathrm{O}$ manure \\
\hline & & $\mathrm{CO}_{2}$ fossil fuels \\
\hline & Soil/water quality & Nutrient cycling \\
\hline & & Acidification processes \\
\hline & & Eutrophication processes \\
\hline & & Water balance \\
\hline & & Soil quality \\
\hline
\end{tabular}

\subsection{Model Selection and Description}

Among the wide variety of farm-level sustainability assessment tools available, wholefarm models represent one of the most frequently used typologies to quantify the sustainability of farms. In order to identify whole-farm models that can be used to test the proposed evaluation framework, a literature search was carried out using the Scopus database. We searched for the presence of the terms "dairy farm", "model", and "sustainability" in the title, abstract, or keywords. The literature search took place in December 2020.

As a primary output, 105 references were identified, from which 3 different models (Table 3) containing the following criteria were selected: (i) published in English-language peer-reviewed journals; (ii) specialized models dealing with DPS; (iii) clearly defined boundaries (whole-farm) in the models; and (iv) integration of all 3Ps of sustainability (environmental, economic, and social).

Table 3. Final literature review output for the identification of models to be tested.

\begin{tabular}{|c|c|c|c|c|c|}
\hline Model & Full Name & References & Origin & $\begin{array}{c}\text { Data } \\
\text { Requirements }\end{array}$ & Main Outputs \\
\hline SIMS $_{\text {DAIRY }}$ & $\begin{array}{l}\text { Sustainable and } \\
\text { Integrated } \\
\text { Management } \\
\text { Systems for Dairy } \\
\text { Production }\end{array}$ & {$[37,38]$} & $\begin{array}{l}\text { United Kingdom } \\
\text { and Spain }\end{array}$ & $\begin{array}{c}\text { Herd } \\
\text { characteristics, diet } \\
\text { composition, farm } \\
\text { management, } \\
\text { biophysical } \\
\text { characteristics }\end{array}$ & $\begin{array}{l}\text { Nutrient flows, GHG } \\
\text { emissions, herd performance, } \\
\text { socioeconomic sustainability } \\
\text { and animal welfare and ES }\end{array}$ \\
\hline GAMEDE & $\begin{array}{l}\text { Global Activity } \\
\text { Model for } \\
\text { Evaluation of the } \\
\text { Sustainability of } \\
\text { Dairy Enterprises }\end{array}$ & {$[39,40]$} & France & $\begin{array}{c}\text { Herd } \\
\text { characteristics, diet } \\
\text { composition, farm } \\
\text { management and } \\
\text { biophysical } \\
\text { characteristics }\end{array}$ & $\begin{array}{c}\text { Nitrogen dynamics, forage } \\
\text { and herd performance, and } \\
\text { work requirements }\end{array}$ \\
\hline
\end{tabular}


Table 3. Cont.

\begin{tabular}{|c|c|c|c|c|c|}
\hline Model & Full Name & References & Origin & $\begin{array}{c}\text { Data } \\
\text { Requirements }\end{array}$ & Main Outputs \\
\hline WLGP & $\begin{array}{l}\text { Weighted Linear } \\
\text { Goal Programming } \\
\text { Model for Dairy } \\
\text { Farms }\end{array}$ & {$[41,42]$} & The Netherlands & $\begin{array}{c}\text { Herd } \\
\text { characteristics, diet } \\
\text { composition, farm } \\
\text { management, and } \\
\text { socio-economic } \\
\text { performance }\end{array}$ & $\begin{array}{c}\text { Nutrient flows, GHG } \\
\text { emissions, economic } \\
\text { performance, working } \\
\text { conditions, animal welfare } \\
\text { and ES }\end{array}$ \\
\hline
\end{tabular}

\subsubsection{SIMS $_{\text {DAIRY }}$}

The Sustainable and Integrated Management Systems for Dairy Production, or SIMS DAIRY, is a modelling framework that integrates the fundamental aspects of the management of a

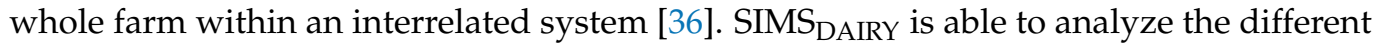
interactions among farm management, genetics, climatic conditions, and environmental characteristics on a monthly basis and check the effects of these on GHG emissions, economic factors, and nutrient flows, as well as other sustainability attributes such as biodiversity, animal welfare, milk quality, and soil quality.

Originally developed for the framework of the United Kingdom (UK), SIMS $\mathrm{SAIRY}_{\text {has }}$ proven its suitability for modelling the integrated sustainability of different production systems (organic, conventional, etc.). The semimechanistic approach used by SIMS DAIRY allows for the simulation of environmental pollution losses with an assessment of financial and socioeconomic sustainability. In addition, SIMS DAIRY is able to simulate the tradeoffs and synergies between the different components of the model, thus optimizing the management practices to achieve more sustainable livestock activity.

\subsubsection{GAMEDE}

The Global Activity Model for Evaluating the Sustainability of Dairy Enterprises, or GAMEDE, is a modelling approach that aims to represent dynamic livestock systems [39]. This whole-farm scale model aims to assess the consequences of a farmer's daily management decisions on whole-farm sustainability on an annual basis (intra-annual variability is also described). GAMEDE is a hybrid model that incorporates mutually dependent variables, thus representing the state of the livestock system at all times. Developed in a temperate climate context, GAMEDE is presented as a model that is potentially applicable to any other geoclimatic context.

Composed of more than 26,000 variables, GAMEDE was designed as a stock-flow model aimed at representing the operation and management of a farm and its effects on technical-economic viability, respect for the environment, and social livability. By quantifying the existing interactions in such a complex system, the user can better understand the processes regulating the nitrogen dynamics within the farm and the factors determining farmers' decisions and practices [40].

\subsubsection{WLGP}

The Weighted Goal Linear Programming-model (WGLP) for dairy farms is a sustainability assessment tool that integrates the economic, social, and environmental sustainability aspects of a dairy farm [41]. This whole-farm model analyzes the interrelations between the biophysical, economic, and social processes (internal and external) of a dairy farm. Designed for Dutch milk production systems, the model aims to analyze the sustainability of DPS from the perspective of individual aspects related to each sustainability pillar or from an integrated perspective, taking into account the preferences of potential stakeholders.

This model integrates a multiattribute function that allows the sustainability of the different production systems analyzed to be maximized. In this way, the model is not only able to identify the impact of different management practices, but it can also identify existing synergies and trade-offs. The indicators for each of the pillars were selected by 
potential users (stakeholders) according to their importance, feasibility, and sensitivity. This facilitates the integration of these indicators in an ad hoc general analysis for each production system.

\subsection{Model Evaluation}

The evaluation of the tools was carried out following a threefold approach. First, each model was evaluated by identifying the indicators included in the evaluation framework. The presence or absence of an indicator in the model was indicated in a binary manner (using 0 for absence and 1 for presence).

In a second step, the percentage of indicators included in each model for each sustainability pillar from all established indicators for the related pillar was calculated using the following Equation (1):

$$
\% I_{\text {pillar }}=\left(\frac{N_{\text {pillar }}}{T_{\text {pillar }}} \times 100\right),
$$

where $\% I$ is the percentage of indicators included in the model for each pillar (economic = $e c o n$, social $=$ soc, and environmental $=e n v), N$ is the number of indicators considered by the model for each pillar, and $T$ is the total number of indicators for each pillar. All scores are given as a \% over the total number of indicators assessed for each case.

In a third step, the Integrated Sustainability Score $\left(I S_{\text {score }}\right)$ was calculated. This score was used to evaluate the global percentage with which the models integrated the sustainability indicators proposed by the evaluation framework taking into account the average values of indicators included for each pillar. For this purpose, the following Equation (2) was used:

$$
I S_{\text {score }}=\left[\frac{\left(\left(\frac{N_{e c o n}}{T_{\text {econ }}} \times 100\right)+\left(\frac{N_{s o c}}{T_{\text {soc }}} \times 100\right)+\left(\frac{N_{\text {env }}}{T_{\text {env }}} \times 100\right)\right)}{3}\right],
$$

where ISscore represents the Integrated Sustainability Score.

\section{Results and Discussion}

\subsection{Economic Sustainability}

The economic sustainability of a farm can be defined as its long-term viability [43]. By integrating farm profitability, autonomy, diversification capacity, and durability, models can represent economic sustainability. The SIMS DAIRY $_{\text {and GAMEDE models integrated equal }}$ percentages of economic indicators $(62 \%)$, while a lower number of indicators was observed in the WLGP model (39\%) (Figure 1). Although aspects related to farm profitability, such as "net farm income", "land productivity", "animal efficiency", and "feed efficiency", are assessed by all three models, a lack of detail has been identified when integrating farm diversification into the modelling schemes. In this context, future model developments should incorporate different approaches to quantify "nonfood earnings" and "economic diversification" as descriptors of farm autonomy.

In a scenario where multifunctionality plays an increasingly important role, capturing the economic diversification of a farm can help to represent the different externalities derived from farming activities [44,45]. Identifying, analyzing, and integrating economic returns associated with livestock activity but not directly related to it, such as educational/pedagogical activities, agritourism, and other "nonfood earnings", has a positive effect on the level of detail with which the economic sustainability is assessed. Furthermore, consideration of the milk quality and enhanced nutritional composition of the products (e.g., unsaturated fatty acids) would potentially increase the accuracy with which the models assess "product diversification" and "added-value products" [37,46,47]. Similarly, the use of by-products in the composition of animal feed, energy generation, or fertilizers significantly contributes to farm autonomy by enhancing the "feed self-sufficiency" and 
"economic self-sufficiency" levels while fostering the carbon and nutrient circularity of the farm [48-50].

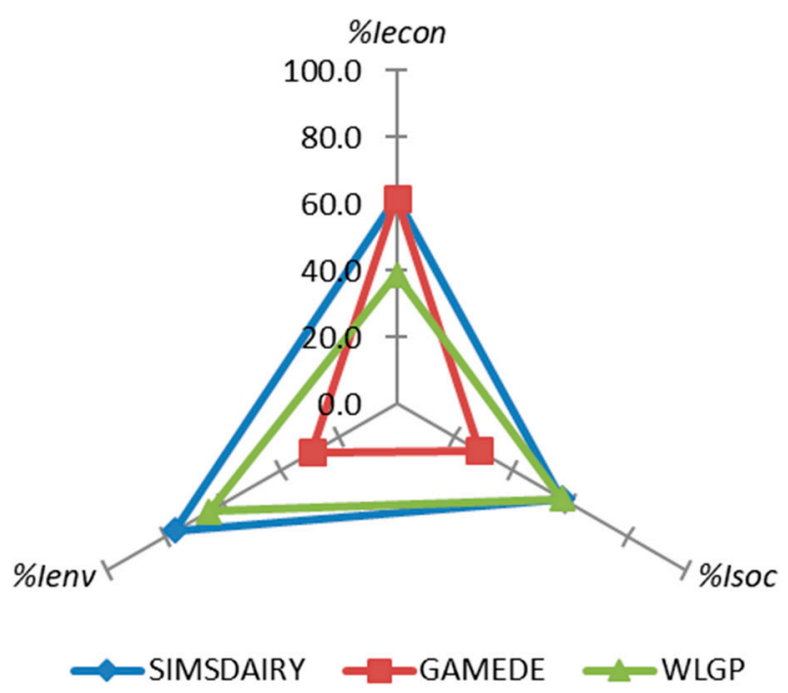

Figure 1. Individual scores obtained for each of the pillars of sustainability by the models included in the evaluation.

Modelling the durability of a farm based on its capacity for "succession and transmissibility" is a major topic that has been addressed by a large number of papers [51-53]. None of the models evaluated incorporate this aspect in their modelling schemes. Due to both the complex assessment process (long-term farm dynamics) and the lack of a consolidated evaluation framework, simplified approaches are needed to capture these aspects [54]. In this context, belonging to farm partnerships or cooperatives has been described as an influential factor in facilitating farm succession and transferability [55,56]. Future model developments should aim to incorporate information on farmers' partnerships in order to integrate this aspect of economic sustainability.

\subsection{Social Sustainability}

In the context of an increasing intensification of DPS, the social pillar of sustainability represents a link between dairy farming and its effects on society. In this regard, the SIMS $_{\text {DAIRY }}$ and WLGP models showed equal levels of inclusion (57\% of the indicators) for indicators related to ecosystem services (ES), animal welfare, and working conditions on the farm. However, the GAMEDE model obtained lower inclusion scores for $29 \%$ of the indicators proposed (Figure 1), all of them describing working conditions on the farm. "Job satisfaction", "personal development", and "work balance" of the farmer are considered fundamental aspects of DPS social sustainability $[57,58]$ that are not fully covered by the three models evaluated. In this context, implementation of the latest available technical and technological advancements in terms of milking systems has been described as a powerful driver for increasing the satisfaction and personal development of farmers [59]. The presence of an automatic milking system on farms has been pointed out as a way of increasing personal well-being and development, since it reduces the amount of time spent on paperwork related to farm management tasks, promotes contact between farmers, reduces workforce needs, optimizes the worktime of farmers, and improves the social perceptions of farming activity $[60,61]$.

Higher educational levels were correlated with greater "labor efficiency" in terms of the use of workforce on farms. An increased level of education was shown to have a positive effect on the average and marginal productivity of a farm [62]. As described in other studies, having a well-established professional development system enables dairy farm workers to improve their professional skills and keeps them in touch with the latest farming techniques [63-65]. Future model developments could consider the 
abovementioned proxies for education level and machinery availability as a way to assess job satisfaction levels, personal development of farmers, work balance, and labor efficiency. Regarding animal welfare, different levels of inclusion were identified for each model.

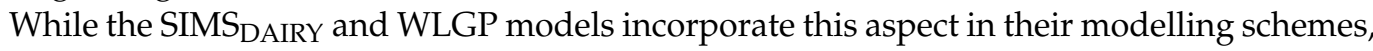
the GAMEDE does not make any reference to it. Both models quantify animal welfare through the use of scores. In the case of the WGLP model, scores are highly dependent on the type of housing present on a farm, as well as the grazing system used [66]. The

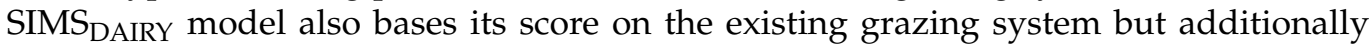
incorporates factors related to the livestock density, animal productivity, and biophysical characteristics of the grazing area [67].

Ecosystem services (ES) are major contributors to social and human well-being and can be considered key indicators for the adequate representation of DPS social sustainability $[68,69]$. The models included in this evaluation were found to have heterogeneous results with regard to the incorporation of ecosystem services (ES) in their modelling schemes. Although the GAMEDE model stresses the importance of the effects of management practices on the biophysical processes of these complex agro-ecosystems, it does not make any explicit reference to the ecosystem services derived from DPS activity in its modelling scheme [39]. By using existing approaches or proxies to identify, incorporate, and assess ES, models should integrate the effects of these aspects into the social pillar of sustainability. This is the case for the SIMS DAIRY and WGLP models [37,41], which include a scoring system for the quantification of environmental conservation, ecosystem regulation, and landscape conservation services. By using indicators related to grazing, the fertilization rate, the seeding and cutting strategy, and soil structure, the model calculates a score that estimates the value of services such as biodiversity, soil quality, and landscape maintenance.

\subsection{Environmental Sustainability}

The ever-growing intensification of DPS has resulted in an increase in the environmental impacts of the sector [70,71]. Whole-farm models should be able to integrate the effects that different management practices have on the environmental pillar of sustainability [72].

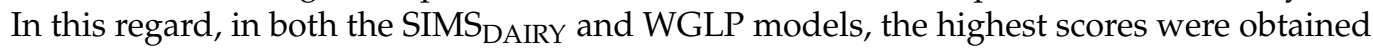
in the environmental pillar, $77 \%$ and $65 \%$, respectively. The GAMEDE model showed a $30 \%$ level of inclusion for the proposed indicators (Figure 1). Differences were observed in both the number and types of farm management attributes integrated by the models. The SIMS $_{\text {DAIRY }}$ and WGLP models integrate aspects related to "land use", "erosion", "energy use", and "water use", while the GAMEDE model only incorporates indicators describing "land use" on a farm. As part of "land use", grazing practices and rotational crops have been described as potential contributors to environmental and social sustainability, given their positive effects on climate change mitigation and their promotion of ES [73,74]. As part of an interconnected system, applying regenerative grazing practices could positively affect the economic and environmental sustainability of the farms by increasing both topsoil carbon storage and spring grass production [75]. The different land uses are reflected by the models through the use of different cover typologies. The GAMEDE model identifies three land-use management-related typologies ranging from grazing to cultivation of varieties for silage or even nonharvesting [40]. In the same way, SIMS DAIRY simplifies the usual on-farm forage covers to four: grass grazed by dairy cows, grass grazed by followers, grass cut for silage, and maize cut for silage. Through this simplification, the model integrates the crops necessary to complete animal dietary requirements that are not covered by concentrates. In addition, this model is capable of determining the risk of "erosion" in the field by estimating sediment loss. Furthermore, the use of pesticides has been associated with negative impacts on the environment due to their elevated ecotoxicity potential [76]. The WGLP model integrates different pesticide typologies depending on the type of crop grown. In this way, the model is able to estimate different associated emissions and impacts [77]. 
Although the relationships among the different livestock activities and the emissions related to their energy consumption has been described by other authors [78], it is necessary to incorporate simple methods for estimating energy consumption as a proxy for future calculation of their associated $\mathrm{CO}_{2}$ emissions. In this regard, the SIMS different types of fuel and electricity consumption to be linked to different activities within a farm. In this way, and by applying different factors for each farm activity (e.g., milk production, field operations, slurry management, feeding practices, etc.), the model enables estimation of the consequent $\mathrm{CO}_{2}$ emissions [79]. Furthermore, while aspects related to the "water balance" are addressed by the models evaluated, "water use" remains one of the most challenging aspects to model within the DPS. Water consumption by dairy farms is largely conditioned by the climatic conditions, evapotranspiration, herd characteristics, and animal performance [80,81].

GHG emissions, nitrogen losses, and associated processes, such as "eutrophication" and "acidification", stand out as the major negative consequences of farming activities [82].

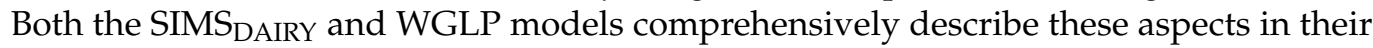
modelling schemes, while GAMEDE only considers nutrient cycling and $\mathrm{CO}_{2}$ emissions in its modelling scheme. In the context of better integration of these environmental impacts, emissions derived from enteric fermentation, animal excreta, and manure management have been described as the main contributors to the negative consequences of DPS, mainly due to emissions of $\mathrm{CH}_{4}, \mathrm{NH}_{3}, \mathrm{NO}_{\mathrm{X}}$, and $\mathrm{NO}_{2}$, both to the atmosphere as well as to soil and water [83]. In this regard, diet composition has usually been described as a key indicator when modelling these emissions [84]. This fact has been widely assessed by other authors, who have pointed out the relationship of GHG emissions and nitrogen loses with the composition of the diet (protein, fiber, fat, dry matter, etc.) as well as the manure management practices [85-88]. For the latter, different manure storage and application strategies have been associated with different levels of $\mathrm{CH}_{4}, \mathrm{~N}_{2} \mathrm{O}$, and $\mathrm{NH}_{3}$ emissions. The three models evaluated in this study incorporate comprehensive indicators related to manure management, such as manure type, storage systems, and applications rates, in their modelling schemes. Under the scenario of an increase in the amount of waste derived from the activity of DPS, the valorization of these by-products is presented as system-based solution for GHG emission mitigation in the context of the circular bioeconomy [89,90]. Models could analyze the role of biogas plants in their modelling schemes by integrating metrics related to the quantity of energy produced, the amount of subproduct used, and the operating costs, contributing significantly to the level of detail with which the model assesses this pillar of sustainability [89].

\subsection{Overall Sustainability}

The calculation of the Integrated Sustainability Score (ISscore) for each of the three models showed different results for the tools evaluated. The quantitative analysis of the indicators integrated by each model identified the SIMS DAIRY model as the one with the highest level of integration of the sustainability indicators, obtaining an ISscore result of $65 \%$. The ISscore for the WLGP model was 53\%, and the GAMEDE model had the lowest overall value, $40 \%$ (Figure 2 ).

This study focused on the design, application, and testing of a quantitative method for the evaluation of whole-farm models oriented toward the analysis of the integrated sustainability of DPS. Further refinements of the framework should focus on incorporating this two-fold approach in the evaluation process by assessing both the total number of indicators included as well as their type and importance. In this context, many authors have highlighted the need to progress toward sustainability assessment models that encompass both the number of indicators and their roles in the context in which they are obtained [91,92]. The variability and vulnerability of the sector highlights the need to incorporate mechanisms that allow the adoption of context-specific solutions [93]. Hence, stakeholder participation processes as part of multicriteria decision-aid methods are valuable approaches that can be used to seek weighted solutions to the challenges faced by 
the sector in each context $[94,95]$. These methods set up tailored weights to the different indicators evaluated, facilitating the integration of a qualitative analysis in a transparent, flexible, and feasible way, making it possible to reach specific sustainability solutions in a more efficient manner [96]. In this regard, through a joint assessment, models should be able to increase the level of information available to potential users of these tools and, consequently, facilitate the choice of one or more tools, depending on their needs.

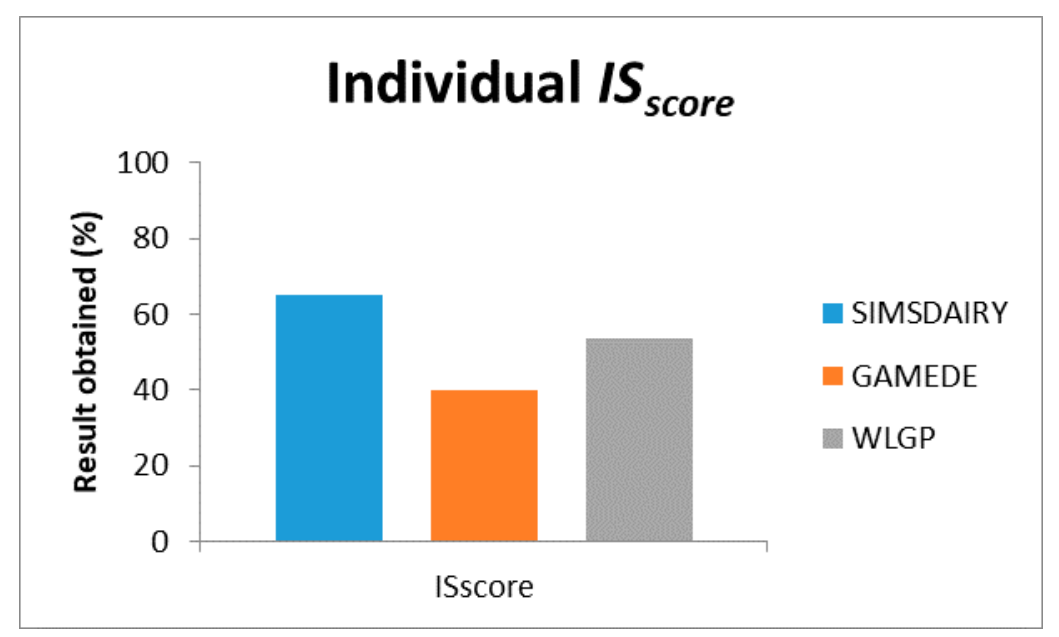

Figure 2. Individual Integrated Sustainability Scores (ISscore) obtained for each model evaluated.

\section{Conclusions}

In conclusion, this whole-farm model evaluation framework is presented as an innovative tool that gives the user a clear overview of the characteristics of each model by describing the degree to which the integrated sustainability of the DPS is assessed. As a consequence, informed decisions can be made by the user when choosing one model over another. Of the whole-farm models evaluated, the SIMS DAIRY model was found to be the one that integrates the aspects proposed by the evaluation framework to the greatest extent.

Even though indicators of the 3P pillars of sustainability are already included in the three evaluated models, future development of the models should include the identification and integration of the social and economic aspects of DPS sustainability in a more comprehensive manner. In addition, further improvement of the evaluation framework by incorporating a qualitative analysis using focus groups, interviews, and surveys could be beneficial for conducting holistic assessments of whole-farm integrated sustainability models for DPS.

Author Contributions: Conceptualization, X.D.d.O.; methodology, X.D.d.O.; investigation, X.D.d.O.; writing—original draft preparation, X.D.d.O.; writing—review and editing, X.D.d.O., A.d.P., F.D., F.E., and B.A.; supervision, A.d.P., F.E., and B.A.; project administration, F.D. and B.A.; funding acquisition, B.A. All authors have read and agreed to the published version of the manuscript.

Funding: This study was financially supported by the German Federal Ministry of Food and Agriculture (BMEL) through the Federal Office for Agriculture and Food (BLE) under grant number 2819ERA08A (MilKey project, funded under the Joint Call 2018 ERA-GAS, SusAn and ICT-AGRI 2 on "Novel technologies, solutions and systems to reduce the greenhouse gas emissions in animal production systems"). BC3-Research is supported by the Spanish Government through María de Maeztu excellence accreditation 2018-2022 (Ref. MDM-2017-0714) and by the Basque Government through the BERC 2018-2021 program. Agustin del Prado is financed through the Ramon y Cajal program by the Spanish Ministry of Economy, Industry, and Competitiveness (RYC-2017-22143).

Institutional Review Board Statement: Not applicable.

Informed Consent Statement: Not applicable.

Data Availability Statement: The study did not report any additional data. 
Conflicts of Interest: The authors declare no conflict of interest.

\section{References}

1. Opio, C.; Gerber, P.; Mottet, A.; Falcucci, A.; Tempio, G.; MacLeod, M.; Vellinga, T.; Henderson, B.; Steinfeld, H. Greenhouse Gas Emissions from Ruminant Supply Chainss-A Global Life Cycle Assessment; Food and Agriculture Organization of the United Nations: Rome, Italy, 2013.

2. $\quad$ van der Ploeg, J.D.; Barjolle, D.; Bruil, J.; Brunori, G.; Costa Madureira, L.M.; Dessein, J.; Drag, Z.; Fink-Kessler, A.; Gasselin, P.; Gonzalez de Molina, M.; et al. The economic potential of agroecology: Empirical evidence from Europe. J. Rural. Stud. 2019, 71, 46-61. [CrossRef]

3. Wodajo, H.D.; Gemeda, B.A.; Kinati, W.; Mulem, A.A.; van Eerdewijk, A.; Wieland, B. Contribution of small ruminants to food security for Ethiopian smallholder farmers. Small Rumin. Res. 2020, 184, 106064. [CrossRef]

4. Bórawski, P.; Dunn, J.; Harper, J.; Pawlewicz, A. The Intra-European Union Trade of Milk and Dairy Products. Acta Sci. Pol. Oecon. 2019, 18, 13-23. [CrossRef]

5. Westhoek, H.J.; Rood, G.A.; van den Berg, M.; Janse, J.H.; Nijdam, D.S.; Reudink, M.A.; Stehfest, E.E. The Protein Puzzle: The Consumption and Production of Meat, Dairy and Fish in the European Union. Eur. J. Nutr. Food Saf. 2011, 1, 123-144.

6. Ghisellini, P.; Protano, G.; Viglia, S.; Gaworski, M.; Setti, M.; Ulgiati, S. Integrated agricultural and dairy production within a circular economy framework. A comparison of Italian and Polish farming systems. J. Environ. Account. Manag. 2014, 2, 367-384. [CrossRef]

7. Lybæk, R.; Kjær, T. Pre-assessment of the circular economic benefits and challenges of biogas production in Denmark when utilizing sand bedding in dairy cow stables. J. Clean. Prod. 2019, 219, 268-277. [CrossRef]

8. European Commission. A Sustainable Bioeconomy for Europe: Strengthening the Connection between Economy, Society and the Environment; European Commission: Brussels, Belgium, 2018; ISBN 9789279941450.

9. Animal Task Force (ATF). Vision Paper towards European Research and Innovation for a Sustainable and Competitive Livestock Production Sector in Europe; Animal Task Force: Paris, France, 2019; pp. 1-35.

10. Clough, T.J.; Rochette, P.; Thomas, S.M.; Pihlatie, M.; Christiansen, J.R.; Thorman, R.E. Global Research Alliance N2O chamber methodology guidelines: Design considerations. J. Environ. Qual. 2020, 49, 1081-1091. [CrossRef] [PubMed]

11. Pérez-Barbería, F.J. The Ruminant: Life History and Digestive Physiology of a Symbiotic Animal. In Sustainable and Environmentally Friendly Dairy Farms; Springer: Cham, Switzerland, 2020; ISBN 9783030460594.

12. Cammarata, M.; Timpanaro, G.; Scuderi, A. Assessing sustainability of organic livestock farming in Sicily: A case study using the Fao Safa framework. Agriculture 2021, 11, 274. [CrossRef]

13. Food and Agricultural Organization of United Nations (FAO). Sustainability Pathways; Food and Agricultural Organization of United Nations: Rome, Italy, 2016.

14. Ma, S.; Acutis, M.; Barcza, Z.; Touhami, H.B.; Doro, L.; Hidy, D.; Köchy, M.; Minet, J.; Lellei-Kovács, E.; Perego, A.; et al. The grassland model intercomparison of the MACSUR (Modelling European Agriculture with Climate Change for Food Security) European knowledge hub. In Proceedings of the 7th International Congress on Environmental Modelling and Software, San Diego, CA, USA, 17 June 2014; Volume 4, pp. 2218-2225.

15. Köchy, M.; Bannink, A.; Banse, M.; Brouwer, F.; Brüser, K.; Foyer, C.; Kipling, R.; Rötter, R.; Scollan, N.; Sinabell, F. MACSUR Phase 1 Final Administrative Report: Public release. FACCE MACSUR Rep. 2015, 6, 3-5.

16. Joint Programming Initiative on Agriculture, Food Security and Climate Change (FACCE-JPI). FACCE-JPI -Strategic Research Agenda 2020; FACCE-JPI: Paris, France, 2020.

17. Kipling, R.P.; Bannink, A.; Bellocchi, G.; Dalgaard, T.; Fox, N.J.; Hutchings, N.J.; Kjeldsen, C.; Lacetera, N.; Sinabell, F.; Topp, C.F.E.; et al. Modeling European ruminant production systems: Facing the challenges of climate change. Agric. Syst. 2016, 147, 24-37. [CrossRef]

18. Schils, R.L.M.; Olesen, J.E.; del Prado, A.; Soussana, J.F. A review of farm level modelling approaches for mitigating greenhouse gas emissions from ruminant livestock systems. Livest. Sci. 2007, 112, 240-251. [CrossRef]

19. Mehrabi, Z.; Gill, M.; van Wijk, M.; Herrero, M.; Ramankutty, N. Livestock policy for sustainable development. Nat. Food 2020, 1 , 160-165. [CrossRef]

20. Adesogan, A.T.; Havelaar, A.H.; McKune, S.L.; Eilittä, M.; Dahl, G.E. Animal source foods: Sustainability problem or malnutrition and sustainability solution? Perspective matters. Glob. Food Secur. 2020, 25, 100325. [CrossRef]

21. Herrero, M.; Henderson, B.; Havlík, P.; Thornton, P.K.; Conant, R.T.; Smith, P.; Wirsenius, S.; Hristov, A.N.; Gerber, P.; Gill, M.; et al. Greenhouse gas mitigation potentials in the livestock sector. Nat. Clim. Chang. 2016, 6, 452-461. [CrossRef]

22. Ibidhi, R.; Calsamiglia, S. Carbon footprint assessment of spanish dairy cattle farms: Effectiveness of dietary and farm management practices as a mitigation strategy. Animals 2020, 10, 2083. [CrossRef]

23. Arulnathan, V.; Heidari, M.D.; Doyon, M.; Li, E.; Pelletier, N. Farm-level decision support tools: A review of methodological choices and their consistency with principles of sustainability assessment. J. Clean. Prod. 2020, 256, 120410. [CrossRef]

24. Coteur, I.; Wustenberghs, H.; Debruyne, L.; Lauwers, L.; Marchand, F. How do current sustainability assessment tools support farmers' strategic decision making? Ecol. Indic. 2020, 114, 106298. [CrossRef]

25. Beukes, P.C.; Palliser, C.C.; Macdonald, K.A.; Lancaster, J.A.S.; Levy, G.; Thorrold, B.S.; Wastney, M.E. Evaluation of a whole-farm model for pasture-based dairy systems. J. Dairy Sci. 2008, 91, 2353-2360. [CrossRef] [PubMed] 
26. Eichler Inwood, S.E.; López-Ridaura, S.; Kline, K.L.; Gérard, B.; Monsalue, A.G.; Govaerts, B.; Dale, V.H. Assessing sustainability in agricultural landscapes: A review of approaches ${ }^{1,2}$. Environ. Rev. 2018, 26, 299-315. [CrossRef]

27. Schils, R.L.M.; De Haan, M.H.A.; Hemmer, J.G.A.; Van Den Pol-van Dasselaar, A.; De Boer, J.A.; Evers, A.G.; Holshof, G.; Van Middelkoop, J.C.; Zom, R.L.G. DairyWise, a wholes-farm dairy model. J. Dairy Sci. 2007, 90, 5334-5346. [CrossRef]

28. Robertson, M.; Pannell, D.; Chalak, M. Whole-farm models: A review of recent approaches. Aust. Farm Bus. Manag. J. 2012, 9 , 13-26.

29. De Olde, E.M.; Oudshoorn, F.W.; Sørensen, C.A.G.; Bokkers, E.A.M.; De Boer, I.J.M. Assessing sustainability at farm-level: Lessons learned from a comparison of tools in practice. Ecol. Indic. 2016, 66, 391-404. [CrossRef]

30. Balaine, L.; Dillon, E.J.; Läpple, D.; Lynch, J. Can technology help achieve sustainable intensification? Evidence from milk recording on Irish dairy farms. Land Use Policy 2020, 92, 104437. [CrossRef]

31. Alem, H. The Role of Technical Efficiency Achieving Sustainable Development: A Dynamic Analysis of Norwegian Dairy Farms. Sustainability 2021, 13, 1841. [CrossRef]

32. Van Passel, S.; Mathijs, E.; Van Huylenbroeck, G. Explaining Differences in Farm Sustainability: Evidence from Flemish Dairy farms. In Proceedings of the International Association of Agricultural Economists Conference, Gold Coast, Australia, 12-18 August 2006; pp. 1-16.

33. Thomassen, M.A.; Dolman, M.A.; van Calker, K.J.; de Boer, I.J.M. Relating life cycle assessment indicators to gross value added for Dutch dairy farms. Ecol. Econ. 2009, 68, 2278-2284. [CrossRef]

34. Galioto, F.; Paffarini, C.; Chiorri, M.; Torquati, B.; Cecchini, L. Economic, environmental, and animal welfare performance on livestock farms: Conceptual model and application to some case studies in Italy. Sustainability 2017, 9, 1615. [CrossRef]

35. Lebacq, T.; Baret, P.V.; Stilmant, D. Sustainability indicators for livestock farming. A review. Agron. Sustain. Dev. $2013,33,311-327$. [CrossRef]

36. Ripoll-Bosch, R.; Díez-Unquera, B.; Ruiz, R.; Villalba, D.; Molina, E.; Joy, M.; Olaizola, A.; Bernués, A. An integrated sustainability assessment of mediterranean sheep farms with different degrees of intensification. Agric. Syst. 2012, 105, 46-56. [CrossRef]

37. Del Prado, A.; Misselbrook, T.; Chadwick, D.; Hopkins, A.; Dewhurst, R.J.; Davison, P.; Butler, A.; Schröder, J.; Scholefield, D. SIMS DAIRY: A modelling framework to identify sustainable dairy farms in the UK. Framework description and test for organic systems and N fertiliser optimisation. Sci. Total Environ. 2011, 409, 3993-4009. [CrossRef]

38. Del Prado, A.; Scholefield, D. Use of SIMSDAIRY modelling framework system to compare the scope on the sustainability of a dairy farm of animal and plant genetic-based improvements with management-based changes. J. Agric. Sci. 2008, 146, 195-211. [CrossRef]

39. Vayssières, J.; Bocquier, F.; Lecomte, P. GAMEDE: A global activity model for evaluating the sustainability of dairy enterprises. Part II-Interactive simulation of various management strategies with diverse stakeholders. Agric. Syst. 2009, 101, 139-151. [CrossRef]

40. Vayssières, J.; Guerrin, F.; Paillat, J.M.; Lecomte, P. GAMEDE: A global activity model for evaluating the sustainability of dairy enterprises Part I-Whole-farm dynamic model. Agric. Syst. 2009, 101, 128-138. [CrossRef]

41. van Calker, K.J.; Berentsen, P.B.M.; Giesen, G.W.J.; Huirne, R.B.M. Maximising sustainability of Dutch dairy farming systems for different stakeholders: A modelling approach. Ecol. Econ. 2008, 65, 407-419. [CrossRef]

42. van Calker, K.J. Sustainability of Dutch Dairy Farming Systems: A Modelling Approach. Ph.D. Thesis, Wageningen University, Wageningen, The Netherlands, 2005.

43. Zorn, A.; Esteves, M.; Baur, I.; Lips, M. Financial ratios as indicators of economic sustainability: A quantitative analysis for Swiss dairy farms. Sustainability 2018, 10, 2942. [CrossRef]

44. Ohe, Y. Evaluating internalization of multifunctionality by farm diversification: Evidence from educational dairy farms in Japan. J. Environ. Manag. 2011, 92, 886-891. [CrossRef]

45. Yoshida, S.; Yagi, H.; Kiminami, A.; Garrod, G. Farm diversification and sustainability of multifunctional peri-urban agriculture: Entrepreneurial attributes of advanced diversification in Japan. Sustainability 2019, 11, 2887. [CrossRef]

46. Alvarez, A.; García-Cornejo, B.; Pérez-Méndez, J.A.; Roibás, D. The profitability of value-added products in dairy farm diversification initiatives. Span. J. Agric. Res. 2018, 16, e0104. [CrossRef]

47. Secco, C.; da Luz, L.M.; Pinheiro, E.; de Francisco, A.C.; Puglieri, F.N.; Piekarski, C.M.; Freire, F.M.C.S. Circular economy in the pig farming chain: Proposing a model for measurement. J. Clean. Prod. 2020, 260, 121003. [CrossRef]

48. Burggraaf, V.T.; Lucci, G.M.; Ledgard, S.F.; Antille, D.L.; Snow, V.O.; de Klein, C.A.M. Application of circular economy principles to new Zealand pastoral farming systems. J. N. Z. Grassl. 2020, 82, 53-59. [CrossRef]

49. Díaz de Otálora, X.; Ruiz, R.; Goiri, I.; Rey, J.; Atxaerandio, R.; San Martin, D.; Orive, M.; Iñarra, B.; Zufia, J.; Urkiza, J.; et al. Valorisation of spent coffee grounds as functional feed ingredient improves productive performance of Latxa dairy ewes. Anim. Feed Sci. Technol. 2020, 264, 114461. [CrossRef]

50. Natalello, A.; Hervás, G.; Toral, P.G.; Luciano, G.; Valenti, B.; Mendoza, A.G.; Pauselli, M.; Priolo, A.; Frutos, P. Bioactive compounds from pomegranate by-products increase the in vitro ruminal accumulation of potentially health promoting fatty acids. Anim. Feed Sci. Technol. 2020, 259, 114355. [CrossRef]

51. Hennessy, T. Modelling succession on Irish dairy farms. In Proceedings of the 10th EAAE Congress 'Exploring Diversity in the European Agri-Food System', Zaragoza, Spain, 28-31 August 2002; pp. 28-31. 
52. Santhanam-Martin, M.; Bridge, P.; Stevens, L. Working with stuckness: Lessons from an intervention to support intergenerational transitions on Australian dairy farms. Can. J. Dev. Stud. 2019, 40, 254-271. [CrossRef]

53. Wheeler, S.; Bjornlund, H.; Zuo, A.; Edwards, J. Handing down the farm? The increasing uncertainty of irrigated farm succession in Australia. J. Rural. Stud. 2012, 28, 266-275. [CrossRef]

54. Leonard, B.; Kinsella, A.; O'Donoghue, C.; Farrell, M.; Mahon, M. Policy drivers of farm succession and inheritance. Land Use Policy 2017, 61, 147-159. [CrossRef]

55. Leonard, B.; Mahon, M.; Kinsella, A.; O’Donoghue, C.; Farrell, M.; Curran, T.; Hennessy, T. The potential of farm partnerships to facilitate farm succession and inheritance. Int. J. Agric. Manag. 2017, 6, 4-19. [CrossRef]

56. Thorsøe, M.; Noe, E.; Maye, D.; Vigani, M.; Kirwan, J.; Chiswell, H.; Grivins, M.; Adamsone-Fiskovica, A.; Tisenkopfs, T.; Tsakalou, E.; et al. Responding to change: Farming system resilience in a liberalized and volatile European dairy market. Land Use Policy 2020, 99, 105029. [CrossRef]

57. Besser, T.; Mann, S. Which farm characteristics influence work satisfaction? An analysis of two agricultural systems. Agric. Syst. 2015, 141, 107-112. [CrossRef]

58. Costa, J.H.C.; Hötzel, M.J.; Longo, C.; Balcão, L.F. A survey of management practices that influence production and welfare of dairy cattle on family farms in southern Brazil. J. Dairy Sci. 2013, 96, 307-317. [CrossRef]

59. Hansen, B.G. Robotic milking-farmer experiences and adoption rate in Jæren, Norway. J. Rural Stud. 2015, 41, 109-117. [CrossRef]

60. Hansen, B.G.; Stræte, E.P. Dairy farmers' job satisfaction and the influence of automatic milking systems. NJAS-Wagening. J. Life Sci. 2020, 92, 100328. [CrossRef]

61. Steeneveld, W.; Tauer, L.W.; Hogeveen, H.; Oude Lansink, A.G.J.M. Comparing technical efficiency of farms with an automatic milking system and a conventional milking system. J. Dairy Sci. 2012, 95, 7391-7398. [CrossRef] [PubMed]

62. Nowak, A.; Kijek, T. The effect of human capital on labour productivity of farms in Poland. Stud. Agric. Econ. 2016, 118, 16-21. [CrossRef]

63. Chen, W.; Holden, N.M. Social life cycle assessment of average Irish dairy farm. Int. J. Life Cycle Assess. 2017, 22, 1459-1472. [CrossRef]

64. Dillon, E.J.; Hennessy, T.; Cullinan, J. The Role of Agricultural Education and Extension in Influencing Best Practice for Managing Mastitis in Dairy Cattle. J. Agric. Educ. Ext. 2016, 22, 255-270. [CrossRef]

65. McDonald, R.; Heanue, K.; Pierce, K.; Horan, B. Factors Influencing New Entrant Dairy Farmer's Decision-making Process around Technology Adoption. J. Agric. Educ. Ext. 2016, 22, 163-177. [CrossRef]

66. Bartussek, H. A review of the animal needs index (ANI) for the assessment of animals' well-being in the housing systems for Austrian proprietary products and legislation. Livest. Prod. Sci. 1999, 61, 179-192. [CrossRef]

67. Müller-Lindenlauf, M.; Deittert, C.; Köpke, U. Assessment of environmental effects, animal welfare and milk quality among organic dairy farms. Livest. Sci. 2010, 128, 140-148. [CrossRef]

68. Costanza, R. Valuing natural capital and ecosystem services toward the goals of efficiency, fairness, and sustainability. Ecosyst. Serv. 2020, 43, 101096. [CrossRef]

69. Schmidt, K.; Sachse, R.; Walz, A. Current role of social benefits in ecosystem service assessments. Landsc. Urban Plan. 2016, 149, 49-64. [CrossRef]

70. Cortez-Arriola, J.; Groot, J.C.J.; Rossing, W.A.H.; Scholberg, J.M.S.; Améndola Massiotti, R.D.; Tittonell, P. Alternative options for sustainable intensification of smallholder dairy farms in North-West Michoacán, Mexico. Agric. Syst. 2016, 144, 22-32. [CrossRef]

71. Eshel, G.; Shepon, A.; Makov, T.; Milo, R. Land, irrigation water, greenhouse gas, and reactive nitrogen burdens of meat, eggs, and dairy production in the United States. Proc. Natl. Acad. Sci. USA 2014, 111, 11996-12001. [CrossRef] [PubMed]

72. Clay, N.; Garnett, T.; Lorimer, J. Dairy intensification: Drivers, impacts and alternatives. Ambio 2020, 49, 35-48. [CrossRef] [PubMed]

73. Teague, R.; Kreuter, U. Managing Grazing to Restore Soil Health, Ecosystem Function, and Ecosystem Services. Front. Sustain. Food Syst. 2020, 4, 1-13. [CrossRef]

74. Zhang, R.; Wang, J.; Niu, S. Toward a sustainable grazing management based on biodiversity and ecosystem multifunctionality in drylands. Curr. Opin. Environ. Sustain. 2021, 48, 36-43. [CrossRef]

75. Díaz de Otálora, X.; Epelde, L.; Arranz, J.; Garbisu, C.; Ruiz, R. Regenerative rotational grazing management of dairy sheep increases springtime grass production and topsoil carbon storage. Ecol. Indic. 2021, 125, 107484. [CrossRef]

76. Huijbregts, M.A.J.; Thissen, U.; Jager, T.; Van De Meent, D.; Ragas, A.M.J. Priority assessment of toxic substances in life cycle assessment. Part II: Assessing parameter uncertainty and human variability in the calculation of toxicity potentials. Chemosphere 2000, 41, 575-588. [CrossRef]

77. Van Calker, K.J.; Berentsen, P.B.M.; De Boer, I.M.J.; Giesen, G.W.J.; Huirne, R.B.M. An LP-model to analyse economic and ecological sustainability on Dutch dairy farms: Model presentation and application for experimental farm "de Marke. " Agric. Syst. 2004, 82, 139-160. [CrossRef]

78. De Haan, M.; Schils, R.L.M.; Hemmer, J.G.A.; Dasselaar, A.V.D.P.; Holshof, G.; van Middelkoop, J.C. Model Documentation: DairyWise; Animal Sciences Group: Lelystad, The Netherlands, 2007.

79. Todde, G.; Murgia, L.; Caria, M.; Pazzona, A. Dairy Energy Prediction (DEP) model: A tool for predicting energy use and related emissions and costs in dairy farms. Comput. Electron. Agric. 2017, 135, 216-221. [CrossRef] 
80. Higham, C.D.; Horne, D.; Singh, R.; Kuhn-Sherlock, B.; Scarsbrook, M.R. Water use on nonirrigated pasture-based dairy farms: Combining detailed monitoring and modeling to set benchmarks. J. Dairy Sci. 2017, 100, 828-840. [CrossRef]

81. Shine, P.; Scully, T.; Upton, J.; Shalloo, L.; Murphy, M.D. Electricity \& direct water consumption on Irish pasture based dairy farms: A statistical analysis. Appl. Energy 2018, 210, 529-537. [CrossRef]

82. Hennessy, D.; Delaby, L.; van den Pol-van Dasselaar, A.; Shalloo, L. Increasing grazing in dairy cow milk production systems in Europe. Sustainability 2020, 12, 2443. [CrossRef]

83. Dijkstra, J.; Bannink, A.; Bosma, P.M.; Lantinga, E.A.; Reijs, J.W. Modeling the Effect of Nutritional Strategies for Dairy Cows on the Composition of Excreta Nitrogen. Front. Sustain. Food Syst. 2018, 2, 1-16. [CrossRef]

84. Kidane, A.; Øverland, M.; Mydland, L.T.; Prestløkken, E. Interaction between feed use efficiency and level of dietary crude protein on enteric methane emission and apparent nitrogen use efficiency with Norwegian Red dairy cows. J. Anim. Sci. 2018, 96, 3967-3982. [CrossRef]

85. Gerber, P.J.; Hristov, A.N.; Henderson, B.; Makkar, H.; Oh, J.; Lee, C.; Meinen, R.; Montes, F.; Ott, T.; Firkins, J.; et al. Technical options for the mitigation of direct methane and nitrous oxide emissions from livestock: A review. Animal 2013, 7, 220-234. [CrossRef]

86. Ouatahar, L.; Bannink, A.; Lanigan, G.; Amon, B. Modelling the Effect of Feeding Management on Greenhouse Gas and Nitrogen Emissions in Cattle Farming Systems. Sci. Total Environ. 2021, 776, 145932. [CrossRef]

87. Petersen, S.O. Greenhouse gas emissions from liquid dairy manure: Prediction and mitigation. J. Dairy Sci. 2018, 101, 6642-6654. [CrossRef]

88. Ricci, P.; Rooke, J.A.; Nevison, I.; Waterhouse, A. Methane emissions from beef and dairy cattle. J. Anim. Sci. 2013, 1-11. [CrossRef]

89. Garcia, D.J.; Lovett, B.M.; You, F. Considering agricultural wastes and ecosystem services in Food-Energy-Water-Waste Nexus system design. J. Clean. Prod. 2019, 228, 941-955. [CrossRef]

90. Parfitt, J.; Barthel, M.; MacNaughton, S. Food waste within food supply chains: Quantification and potential for change to 2050. Philos. Trans. R. Soc. B Biol. Sci. 2010, 365, 3065-3081. [CrossRef] [PubMed]

91. Reid, J.; Rout, M. Developing sustainability indicators-The need for radical transparency. Ecol. Indic. 2020, $110,105941$. [CrossRef]

92. Scerri, A.; James, P. Accounting for sustainability: Combining qualitative and quantitative research in developing "indicators" of sustainability. Int. J. Soc. Res. Methodol. 2010, 13, 41-53. [CrossRef]

93. de Asís Ruiz Morales, F.; Genís, J.M.C.; Guerrero, Y.M. Current status, challenges and the way forward for dairy goat production in Europe. Asian-Australas. J. Anim. Sci. 2019, 32, 1256-1265. [CrossRef] [PubMed]

94. Belanche, A.; Martín-Collado, D.; Rose, G.; Yáñez-Ruiz, D.R. A multi-stakeholder participatory study identifies the priorities for the sustainability of the small ruminants farming sector in Europe. Animal 2021, 15, 100131. [CrossRef]

95. Martín-Collado, D.; Díaz, C.; Mäki-Tanila, A.; Colinet, F.; Duclos, D.; Hiemstra, S.J.; Gandini, G. The use of SWOT analysis to explore and prioritize conservation and development strategies for local cattle breeds. Animal 2013, 7, 885-894. [CrossRef] [PubMed]

96. Sadok, W.; Angevin, F.; Bergez, J.E.; Bockstaller, C.; Colomb, B.; Guichard, L.; Reau, R.; Messéan, A.; Doré, T. MASC, a qualitative multi-attribute decision model for ex ante assessment of the sustainability of cropping systems. Agron. Sustain. Dev. 2009, 29, 447-461. [CrossRef] 